\title{
Suppressive effects of a selective inducible nitric oxide synthase (iNOS) inhibitor on pancreatic beta-cell dysfunction
}

\author{
Y. Kato, Y. Miura, N. Yamamoto, N. Ozaki, Y. Oiso \\ Department of Endocrinology and Diabetology, Nagoya University School of Medicine, Showa-ku, Nagoya, Japan
}

\begin{abstract}
Aims/hypothesis. Type 1 diabetes mellitus is an autoimmune disease characterized by dysfunction and destruction of the pancreatic beta cells. Interleukin- $1 \beta$ (IL-1 $\beta$ ) has been reported to cause suppression of insulin secretion from pancreatic islets via induction of inducible nitric oxide synthase (iNOS) followed by nitric oxide (NO) production. In this study, we investigated the effects of inhibition of iNOS on pancreatic beta-cell dysfunction in non-obese diabetic (NOD) mice and IL-1 $\beta$-treated isolated rat pancreatic islets using a novel specific inhibitor, ONO-1714.

Methods. Female NOD mice which received subcutaneous infusion of ONO-1714 (4 $\mu \mathrm{g} / \mathrm{kg} / \mathrm{day}$ or $40 \mu \mathrm{g} / \mathrm{kg} /$ day) from 10 to 14 weeks after birth were compared with untreated NOD mice. In addition, pancreatic islets were isolated from Sprague-Dawley rats and cultured for $24 \mathrm{~h}$ with IL-1 $\beta(100 \mathrm{U} / \mathrm{mL})$ with or without ONO-1714 or the non-selective NOS inhibitor $\mathrm{NG}^{\mathrm{G}}$-monomethyl-L-arginine (L-NMMA). We measured insulin secretion and insulin content of the islets
\end{abstract}

by ELISA, iNOS mRNA expression by reverse transcription-polymerase chain reaction, and NO generation by Griess Reagent System.

Results. Hyperglycaemia was observed in NOD mice. ONO-1714 treatment blunted this increase and tended to preserve insulin secretion, although body weight increase did not differ between the groups. Insulitis was also attenuated in the ONO-1714-administered group compared to the control group. Furthermore, in isolated rat pancreatic islets ONO-1714 prevented IL-1 $\beta$-induced inhibition of insulin secretion, this protection being evident in much lower concentrations than with L-NMMA. While ONO-1714 completely inhibited IL- $\beta \beta$-induced NO production, it did not reduce expression of islet iNOS mRNA.

Conclusion/interpretation. These findings indicate that ONO-1714 is promising as a therapeutic agent for autoimmune diabetes. [Diabetologia (2003) 46: 1228-1233]

Keywords Type 1 DM, interleukin- $1 \beta$, NOD mouse, pancreatic islet, iNOS, nitric oxide, ONO-1714.
Received: 24 February 2003 / Revised: 5 May 2003

Published online: 24 July 2003

C) Springer-Verlag 2003

Corresponding author: Y. Miura MD PhD, Department of Endocrinology and Diabetology, Nagoya University School of Medicine, 65 Tsurumai-cho, Showa-ku, Nagoya 466-8550, Japan

E-mail: ymiura64@med.nagoya-u.ac.jp

Abbreviations: iNOS, inducible nitric oxide synthase; NO, nitric oxide; NOD, non-obese diabetic; IL-1 $\beta$, interleukin-1 $\beta$; L-NMMA, $\mathrm{NG}^{\mathrm{G}}$-monomethyl-L-arginine; eNOS, endothelial NOS; L-NAME, ${ }^{\omega}{ }^{\omega}$-nitro-L-arginine methyl ester; AG, aminoguanidine.
Type 1 diabetes mellitus is characterized by infiltration of the pancreatic islets by mononuclear cells followed by dysfunction and destruction of the pancreatic beta cells [1]. The proinflammatory cytokine interleukin-1 $\beta$ (IL-1 $\beta$ ) produced by infiltrating mononuclear cells has been implicated as an immunological effector which both inhibits insulin secretion by pancreatic beta cells and induces their destruction $[2,3,4,5$, $6]$. The deleterious effects of IL-1 $\beta$ are thought to be mediated by production of nitric oxide (NO) [7, 8, 9], resulting from the expression of the cytokine-inducible isoform of NO synthase (iNOS) $[10,11]$, in islet 
infiltrating macrophages as well as in beta cells themselves $[7,12,13,14,15]$. NO leads to destruction of the iron-sulfur centres of iron-containing enzymes and results in an impairment of mitochondrial function and ATP synthesis [16]. Thus, as a strategy for prevention of autoimmune diabetes mellitus, inhibition of NO generation could be beneficial. It has been shown that the non-selective NOS inhibitor $\mathrm{N}^{\mathrm{G}}$-monomethyl$\mathrm{L}$-arginine (L-NMMA) improves IL-1 $\beta$-induced impairment of insulin secretion in vitro [17, 18, 19, 20], although it is difficult to use this agent as a therapeutic tool in vivo because of its side effects that result from the inhibition of the constitutive isoforms of NOS, which are linked physiological actions of NO. The novel cyclic amidine analog, ONO-1714, is one of the most potent and selective iNOS inhibitors currently available [21]. It is reported to be 10-fold more active against human iNOS than human endothelial NOS (eNOS), and 451-fold more potent than L-NMMA regarding inhibition of the inducible isoform. In fact it has been shown to be approximately 34 -fold more selective for human iNOS [21]. Here we report beneficial effects of ONO-1714 in terms of retardation of diabetes progression in the non-obese diabetic (NOD) mouse, a spontaneous animal model of Type 1 diabetes, and improvement of IL-1 $\beta$-induced inhibition of insulin secretion in isolated rat pancreatic islets.

\section{Methods}

Reagents. Recombinant human IL-1 $\beta$ was purchased from Pepro Tech EC, London, UK. (1S, 5S, 6R, 7R)-7-Chloro-3-imino-5methyl-2-azabicyclo-[4.1.0] heptane hydrochloride (ONO-1714) was a generous gift from ONO Pharmaceutical Co., Osaka, Japan and L-NMMA was purchased from Sigma, St Louis, Mo., USA.

Animals. Female NOD mice and male Sprague-Dawley (SD) rats were obtained from Nippon SLC, Shizuoka, Japan and housed in a temperature-, humidity-, and light-controlled room $\left(21-23^{\circ} \mathrm{C}, 12 \mathrm{~h}-12 \mathrm{~h}\right.$ light-dark cycle) and given free access to food and water. The institutional ethical committee for animal experiments approved all the protocols.

NOD mouse experiment. We administrated either a low dose $(4 \mu \mathrm{g} / \mathrm{kg} /$ day, $n=6)$ or a high dose $(40 \mu \mathrm{g} / \mathrm{kg} /$ day, $n=5)$ of ONO1714 for 4 weeks via continuous subcutaneous infusion to 10 week-old female NOD mice using osmotic mini pumps (Alzet, Cupertino, Calif., USA). Untreated control mice $(n=5)$ were administered saline using the same pumps. Intraperitoneal glucose tolerance tests $(1.5 \mathrm{mg} / \mathrm{g}$ body weight) were carried out after 4 weeks administration of the compound. Plasma glucose concentrations were measured using a compact glucose analyzer (Medi Safe, Terumo, Tokyo, Japan) with orbital blood sampling. After the experiments, mice were killed by cervical dislocation under sodium pentobarbital anaesthesia and pancreatic tissue was removed, fixed in $10 \%$ formalin and embedded in paraffin. Each pancreatic block was cut into $5 \mu \mathrm{m}$ thin sections and stained with haematoxilin and eosin and observed under a light-microscope for evaluation of insulitis, classified into three categories by the degree of mononuclear cell infiltration into islets: high
(80\% ), moderate $(20 \sim 80 \%)$ and low ( 20\%). In each pancreas, approximately 30 islets were analyzed and a total of 150 islets in each experimental group were evaluated for insulitis. The examiner was unaware of the origin of the sections.

Islet isolation and culture. Rat pancreatic islets were isolated from male SD rats (7-10 weeks of age) using collagenase digestion, after addition of IL-1 $\beta$ and/or inhibitors, and cultured in RPMI 1640 medium (Invitrogen, Carlsbad, Calif., USA) supplemented with antibiotics $(50 \mu \mathrm{U} / \mathrm{ml}$ penicillin and $50 \mu \mathrm{g} / \mathrm{ml}$ streptomycin), and $10 \%$ foetal calf serum (Dainippon Pharmaceutical, Osaka, Japan) for $24 \mathrm{~h}$ at $37^{\circ} \mathrm{C}$ in $5 \% \mathrm{CO}_{2}$ and $95 \%$ air.

Insulin release from the isolated pancreatic islets. The control and treated islets were pre-incubated at $37^{\circ} \mathrm{C}$ for $20 \mathrm{~min}$ with Hepes-Krebs buffer supplemented with $3.3 \mathrm{mmol} / \mathrm{l}$ glucose and $0.1 \%$ BSA, fraction V (Sigma, St Louis, Mo., USA). Groups of five islets were then incubated for $30 \mathrm{~min}$ at $37^{\circ} \mathrm{C}$ in $500 \mu \mathrm{l}$ of Hepes-Krebs buffer containing $16.7 \mathrm{mmol} / \mathrm{l}$ glucose. Samples of incubation buffer were collected for insulin determination with ELISA (Shibayagi, Gunma, Japan). Insulin content of islets was measured by ELISA after acid-ethanol extraction.

Determination of cell viability. The cell viability was evaluated by the Trypan blue exclusion assay. Control islets and IL-1 $\beta$ and/or inhibitor-treated islets were dispersed and examined microscopically.

Semi-quantitative RT-PCR of iNOS mRNA. Total RNA was isolated from rat islets using TRIzol reagent (Invitrogen) and used for the reverse transcription reaction with reverse transcriptase (SuperScript Preamplification System, Invitrogen) according to the manufacturer's protocol. The cDNA was subjected to PCR for rat iNOS and GAPDH as an internal control with rTaq DNA polymerase (Takara Shuzo, Tokyo, Japan). Primers for rat iNOS cDNA were as follows; sense-5'-CAGCAATGGGCAGACTCT-3', antisense-5'-CACAGGCTGCCCGGAAGGTTTG-3'. Primers for GAPDH cDNA were as follows; sense 5'-GTCCCGTAGACAAAATGGTG-3', antisense 5'-GCTTCACCACCTTCTTGATG-3'. PCR conditions for iNOS were: $1 \mathrm{~min}$ at $94^{\circ} \mathrm{C}, 1 \mathrm{~min}$ at $60^{\circ} \mathrm{C}$, and $1 \mathrm{~min}$ at $72^{\circ} \mathrm{C}$ for 30 cycles. For GAPDH, they were $1 \mathrm{~min}$ at $94^{\circ} \mathrm{C}, 1 \mathrm{~min}$ at $55^{\circ} \mathrm{C}$, and $1 \mathrm{~min}$ at $72^{\circ} \mathrm{C}$ for 30 cycles. PCR products were separated by $1 \%$ agarose gel electrophoresis followed by staining with ethidium-bromide, and the intensity of each band was analyzed with NIH image software (ver. 1.59).

Measurement of nitrite production. Islet NO production was measured as nitrite accumulation in culture media determined by Griess reaction. Groups of 100 islets in $120 \mu$ of RPMI 1640 medium were exposed to IL-1 $\beta$ with or without ONO1714 for $24 \mathrm{~h}$. Samples of the conditioned media were then collected and applied to the Griess Reagent System (Promega, Madison, Wis., USA). The limit of detection is 125 pmol nitrite with this method.

Statistical analysis. Values for insulin secretion, insulin content, cell viability and nitrite concentration were analyzed by ANOVA followed by Fisher's PLSD test for multiple comparisons with Stat View 5 (SAS institute, Cary, N.C., USA). A $p$ value of less than 0.05 was considered statistically significant. Values for histological evaluation of insulitis were analyzed using Spearmann rank correlation. Values for expression of iNOS mRNA were analyzed using non-parametric MannWhitney U-test with Bonferroni correction. In this case, a $p$ value of less than 0.017 was considered significant. 


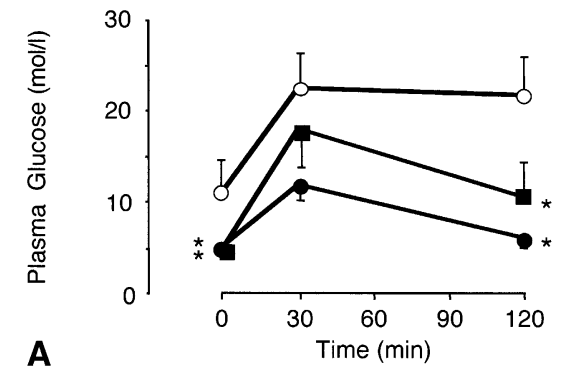

Fig. 1A, B. Plasma glucose (A) and insulin concentrations (B) in the intraperitoneal glucose tolerance test $(1.5 \mathrm{mg} / \mathrm{g}$ body weight) 4 weeks after low dose $(4 \mu \mathrm{g} / \mathrm{kg} /$ day, $n=6)$ or high dose (40 $\mu \mathrm{g} / \mathrm{kg} /$ day, $n=5)$ administration of ONO-1714 in NOD mice. $\bigcirc$, control $(n=5)$; $\mathbf{\square}$, high dose; $\boldsymbol{O}$, low dose. Results are means \pm S.E. $(\mathbf{A}, \mathbf{B}) . * p<0.05$ vs control $(\mathbf{A})$

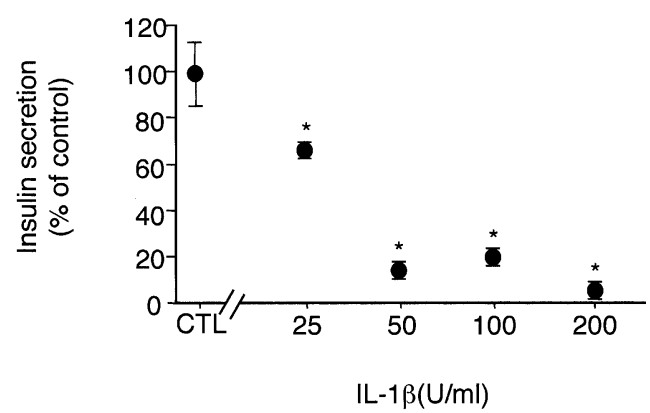

Fig. 2. Effects of IL-1 $\beta$ on glucose-stimulated insulin secretion from isolated rat islets. Rat islets were incubated with 0,25 , $50,100,200 \mathrm{U} / \mathrm{ml}$ of IL-1 $\beta$ for $24 \mathrm{~h}$. Insulin secretion was measured over $30 \mathrm{~min}$ incubation with glucose $16.7 \mathrm{mmol} / \mathrm{l}$, following a $20 \mathrm{~min}$ pre-incubation with glucose $3.3 \mathrm{mmol} / \mathrm{l}$. Insulin secretion is expressed as the percentage of the control value. Results are means \pm S.E. $(n=6) * p<0.05$ vs control

\section{Results}

Effects of ONO-1714 on progression of diabetes in the NOD mouse. The increments of BW after 4 weeks treatment did not differ among the groups. The fasting plasma glucose concentrations were increased in the control group compared to the ONO-1714-treated groups. After glucose loading, plasma glucose concentrations were high in the control group and remained within normal range in the low dose group (Fig. 1A). Insulin secretion was impaired in the control group, but there was a tendency towards preservation by the ONO-1714 administration (Fig. 1B). Histological examination showed that all the mice developed insulitis (Table 1), but the extent was decreased in the ONO1714-administered groups when compared with the control groups $(p<0.01$, high dose vs control and $p<0.001$, low dose vs control). Thus, 4 weeks administration of ONO-1714 retarded the progression of autoimmune diabetes mellitus in NOD mice.

Effects of IL-1 $\beta$ on glucose-stimulated insulin secretion from isolated rat islets. To determine an appropri-

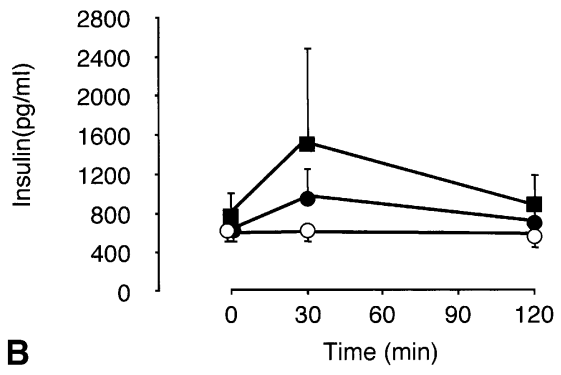

Table 1. Histological evaluation of ONO-1714-treated NOD mice

\begin{tabular}{lllr}
\hline & Low & Moderate & High \\
\hline CTL $(n=5)$ & 14 & 32 & 104 \\
Low-Dose** $(n=6)_{\text {High-Dose* }(n=5)}^{17}$ & 19 & 55 & 68 \\
\hline
\end{tabular}

Insulitis was evaluated with reference to the degree of mononuclear cell infiltration into the islets. The extent of insulitis was classified into three categories by the degree of mononuclear cell infiltration into islets: high $(80 \% \sim)$, moderate (20 80\%) and low ( 20\%). Values are numbers of islets in each category of insulitis, out of a total of 150 islets evaluated for insulitis in each experimental group of mice ( 30 islets evaluated per pancreas). $* p<0.01, * * p<0.001$ vs control

ate concentration of IL-1 $\beta$, isolated rat islets were incubated with various concentrations for $24 \mathrm{~h}$, then, glucose-stimulated insulin secretion was examined (Fig. 2). Dose-dependent suppression of insulin secretion was evident. With $100 \mathrm{U} / \mathrm{ml} \mathrm{IL}-1 \beta$, the value was reduced to $20 \%$ of the control and this concentration was selected for use in the following experiments.

Dose dependent effects of ONO-1714 on glucose-stimulated insulin secretion. ONO-1714 alone did not influence glucose-stimulated insulin secretion, but it prevented the IL-1 $\beta$-induced inhibition in a dose-dependent manner (Fig. 3A). The maximum effect was obtained at the concentration of $10^{-5} \mathrm{~mol}$, and with recovery up to $84 \%$ of the control level. Treatment with IL-1 $\beta$ and/or ONO-1714 did not affect the insulin content in isolated islets (Fig. 3B). Trypan blue staining also showed no difference in cell viability among the groups. The trypan blue stained cells of control cells, IL-1 $\beta$-treated cells and IL- $1 \beta$ - plus ONO1714-treated cells were in the range of $9.3 \pm 0.5 \%$ (means \pm S.E., $n=3), 8.3 \pm 0.5 \%(n=3), 8.2 \pm 1.3 \% \quad(n=3)$, respectively. There were no significant differences in any of three groups.

Dose-dependent effects of L-NMMA on glucose-stimulated insulin secretion. The inhibitory effects on iNOS were compared between ONO-1714 and L-NMMA in isolated rat islets. L-NMMA improved IL-1 $\beta$-induced impairment of glucose-stimulated insulin secretion at higher concentration than ONO-1714 (Fig. 4) consist- 


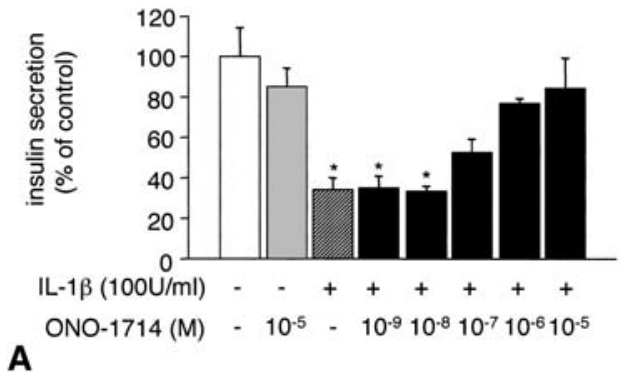

Fig. 3A, B. Effects of a specific iNOS inhibitor (ONO-1714) on insulin secretion from rat islets (A) and their insulin contents (B). Rat islets were cultured with $100 \mathrm{U} / \mathrm{ml} \mathrm{IL-1 \beta}$ and $10^{-9}-10^{-5} \mathrm{~mol} / \mathrm{l}$ ONO-1714 for $24 \mathrm{~h}$. Groups of five islets were incubated at $3.3 \mathrm{mmol} / \mathrm{l}$ glucose for $20 \mathrm{~min}$ followed by $30 \mathrm{~min}$ at $16.7 \mathrm{mmol} / \mathrm{l}$ glucose. Glucose-induced insulin secretion into the incubation medium $(\mathbf{A})$ and insulin content in acid ethanol extracts $(\mathbf{B})$ of the islets were determined by ELISA. An open column indicates the value of control islets, a gray column indicates value of ONO-1714-treated islets, a hatched column indicates value of IL-1 $\beta$-treated islets and filled columns indicate values of both ONO-1714- and IL-1 $\beta$-treated islets. Data are percentages of corresponding control values. Results are means \pm S.E. $(n=6) . * p<0.05$ vs IL-1 $\beta$ (A) and vs control (B)

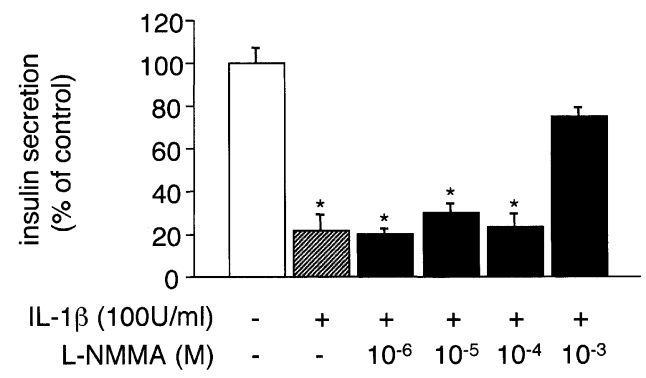

Fig. 4. Effects of L-NMMA on insulin secretion. Rat islets were cultured with $100 \mathrm{U} / \mathrm{ml}$ IL- $1 \beta$ alone or with $10^{-6}-10^{-}$ ${ }^{3} \mathrm{~mol} / \mathrm{l} \mathrm{L}-\mathrm{NMMA}$ for $24 \mathrm{~h}$. Groups of five islets were incubated at $3.3 \mathrm{mmol} / \mathrm{l}$ glucose for $20 \mathrm{~min}$ followed by $30 \mathrm{~min}$ at $16.7 \mathrm{mmol} / \mathrm{l}$ glucose. Insulin released during the incubation period was determined by ELISA. An open column indicates the value of control islets, a gray column indicates the value of LNMMA-treated islets, a hatched column indicates the value of IL-1 $\beta$-treated islets and filled columns indicate values of both L-NMMA- and IL-1 $\beta$-treated islets. Data are percentages of corresponding control values. Results are means \pm S.E. $(n=6)$. $* p<0.05$ vs IL- $1 \beta$

ant with the fact that the inhibitory effect of ONO1714 on iNOS is 451 -fold more potent than L-NMMA.

Semi-quantitative RT-PCR of iNOS mRNA. To investigate whether a specific iNOS inhibitor can affect iNOS mRNA expression in rat islets, semi-quantitative RT-PCR of iNOS mRNA was carried out (Fig. 5). ONO-1714 treatment did not reduce but rather enhanced IL-1 $\beta$-induced iNOS mRNA expression.

Effects of ONO-1714 on IL-1ß-induced NO production. Groups of islets were exposed to IL- $1 \beta$ with or
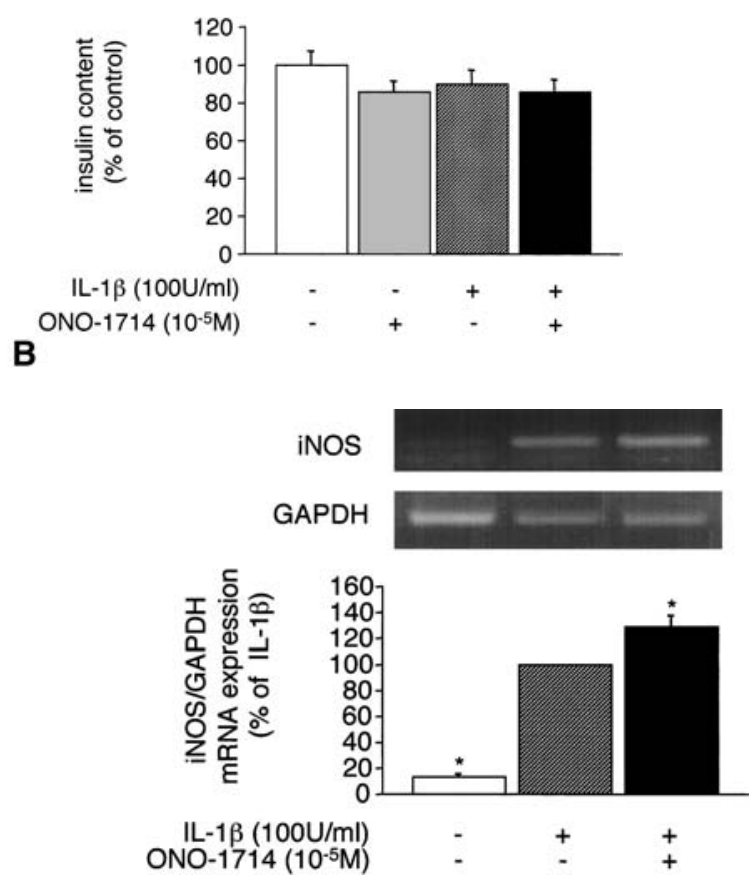

Fig. 5. Effects of ONO-1714 on IL-1 $\beta$-induced iNOS mRNA expression in rat islets. After islets were exposed to IL-1 $\beta$ for $24 \mathrm{~h}$ with or without $10^{-5}$ mol ONO-1714, cDNA was amplified using specific iNOS and GAPDH primers. Representative results are shown in the upper panel. For semiquantification, PCR was carried out and GAPDH was used as an internal control. The ratio of iNOS/GAPDH for each experimental group is shown in the lower panel. An open column indicates value of control islets, a hatched column indicates value of IL- $1 \beta$-treated islets and a filled column indicates value of both ONO1714 - and IL-1 $\beta$-treated islets. Data are from five independent experiments. Results are expressed as the percentages of the corresponding values of IL-1 $\beta$. Values are means \pm S.E. $(n=5)$. $* p<0.017$ vs IL- $1 \beta$

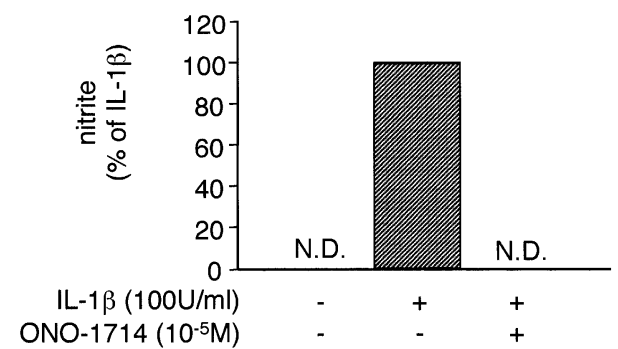

Fig. 6. Effects of ONO-1714 on IL-1 $\beta$-induced NO production. Groups of 100 islets pre-treated with ONO-1714 for $30 \mathrm{~min}$ were exposed to IL- $1 \beta$ for $24 \mathrm{~h}$. The nitrite concentration in the culture media is expressed as the percentage of the corresponding IL-1 $\beta$ value alone. Data are from five independent experiments. The hatched column indicates value of IL$1 \beta$-treated islets. $N D$, not detectable

without the inhibitor for $24 \mathrm{~h}$ (Fig. 6). In control islets they were below the level of detection (125 pmol). The mean value of nitrite in IL-1 $\beta$-treated group was $377 \pm 45$ pmol (means \pm S.E., $n=5$ ), therefore, IL-1 $\beta$ induced NO-production three-fold above the detection 
limit of the assay. IL-1 $\beta$ induced NO production accompanied by increase in iNOS mRNA. ONO-1714 suppressed this IL-1 $\beta$-induced NO production completely.

\section{Discussion}

It is well known that NO produced by the expression of iNOS mediates dysfunction and autoimmune destruction of pancreatic beta cells $[7,8,10]$, and many studies have shown inhibitions of NOS to attenuate IL-1 $\beta$-induced inhibition of glucose-stimulated insulin secretion in isolated islets $[17,18,19,20]$. However, prevention of diabetes development in animal models of Type $1 \mathrm{DM}$ has remained elusive. This study shows beneficial effects of ONO-1714, one of the most potent and selective iNOS inhibitors currently available, on the development of Type $1 \mathrm{DM}$ in vivo as well as associated IL-1 $\beta$ alteration in isolated islets in vitro. Previous studies have shown that a non-selective NOS inhibitor, L-NMMA, can improve IL- $1 \beta$-induced impairment of insulin secretion in vitro, but its inhibition of the endothelial isoform of NOS (eNOS) results in increased blood pressure, making it impossible to apply in vivo. With the administration of ONO-1714 to NOD mice for 4 weeks, from the age of 10 weeks, insulitis and autoimmune diabetes mellitus were ameliorated. NOD mice show pancreatic islet infiltration by cells of the immune system (insulitis) beginning at 5 weeks of age, the prevalence of insulitis being $90 \%$ at 9 weeks of age and $100 \%$ at 20 weeks, with beta-cell destruction and diabetes beginning at 12 weeks of age. Therefore, we administered the iNOS inhibitor to NOD mice when insulitis had developed but beta-cell destruction had not yet emerged. If inhibition of NO formation in beta cells of NOD mice prevents progression of autoimmune diabetes mellitus, this would indicate a pathogenic role for iNOS and NO in autoimmune destruction of beta cells. Our results showed that ONO-1714 could also protect pancreatic islets of NOD mice against mononuclear cell infiltration, suggesting the possibilities that antigen presentation to immunocytes along with mononuclear cell chemotaxis was suppressed due to suppression of NO-induced beta-cell destruction by ONO-1714. Furthermore, we hypothesized that ONO-1714 might have the direct effect of suppression of mononuclear cell infiltration to the islet. Thus, ONO-1714 might protect islets by reduction of both immune system attack and NO-mediated actions of cytokines secreted from infiltrating mononuclear cells. Many studies carried out in vitro have clearly shown that inhibition of iNOS by analogs of L-arginine improves functional activity of islets exposed to cytokines. For example, L-NMMA and $\mathrm{N}^{\omega}$-nitro-L-arginine methyl ester (L-NAME) preserve glucose-induced insulin secretion in islets exposed to IL-1 $\beta[17,18]$. However, results from in vivo studies using animal models of Type 1 diabetes mellitus have been controversial. Administration of L-NMMA, aminoguanidine (AG), another type of iNOS inhibitor, or L-NAME to diabetic prone BB-rats reduced diabetes incidence [22, 23]. Furthermore, treatment with AG prevented or delayed the development of diabetes in transgenic mice overexpressing iNOS in pancreatic beta cells [24]. In contrast, L-NMMA or AG in NOD mice did not show any effects on the incidence of diabetes $[25,26]$. Recently, however, one study reported that a selective iNOS inhibitor guanidinoethyldisulphide protects progression of diabetes in the NOD mouse [27] although another such agent, W1400 failed to prevent multiple low-dose streptozotocin-induced diabetes in vivo [28]. Thus, the effects of various iNOS inhibitors in vivo differ greatly. The strategy of suppression of iNOS activity must be viewed critically, since all of the inhibitors might also interact with other NOS isoforms, albeit with lower affinity. High doses of arginine-related compounds have to be administered, which could result in other pharmacological effects. Actually, rats treated with L-NAME showed increased tail-cuff pressure as well as histological lesions resembling the severe cardiomyopathy found in hypertensive-diabetic rats due to the inhibition of eNOS by this compound [29]. We found that NOD mice administered a low dose of ONO-1714 showed more noticeable improvement of plasma glucose concentrations than a high dose, before and after glucose loading. We consider that this result suggests that a high dose of ONO-1714 might have eNOS inhibitory effect and inhibition of eNOS-derived NO might lead to the insulin resistance [30] of NOD mice.

We also investigated the effect of ONO-1714 in isolated rat islets, with beta cells intact and not infiltrated by mononuclear cells. A $100 \mathrm{U} / \mathrm{ml}$ dose of IL-1 $\beta$ showed suppression of glucose-induced insulin secretion, although there were no differences in the insulin content and the result of trypan blue staining as evidence of damage to beta-cell function not associated with cell death. Treatment with $10^{-5}$ mol ONO1714 blocked this effect. Thus, we presume that ONO1714 improves beta-cell function of insulin secretion without affecting beta-cell viability. Although the IL$1 \beta$-induced expression of iNOS mRNA was not reduced, NO formation ceased completely. Thus, inhibition of NO production is responsible to improvement of IL-1 $\beta$-mediated suppression of glucose-stimulated insulin secretion. However, IL- $1 \beta$-mediated inhibition of insulin release was only attenuated to $84 \%$ of the control, indicating an involvement of other mediators of NO-independent signalling pathways. Further elucidation of IL-1 $\beta$-mediated signal transduction pathways in beta cells should facilitate understanding of the pathogenesis of autoimmune Type 1 diabetes mellitus and development of new pharmacological treatments.

In conclusion, this study shows retarding effects of the novel specific iNOS inhibitor ONO-1714 on auto- 
immune diabetes mellitus in the NOD mouse and prevention of IL-1 $\beta$-mediated dysfunction in isolated rat pancreatic islets. The findings indicate that ONO1714 could have a potential as a therapeutic agent for autoimmune Type 1 diabetes mellitus.

\section{References}

1. Castano L, Eisenbarth GS (1990) Type-1 diabetes: a chronic autoimmune disease of human, mouse, and rat. Ann Rev Immunol 8:1053-1058

2. Mandrup-Poulsen T (1996) The role of interleukin-1 in the pathogenesis of IDDM. Diabetologia 39:1005-1029

3. Rabinovitch A (1993) Roles of cytokines in IDDM pathogenesis and islet $\beta$-cell destruction. Diabetes Rev 1:215240

4. Comens PG, Wolf BA, Unanue ER et al. (1987) Interleukin 1 is potent modulator of insulin secretion from isolated rat islets of Langerhans. Diabetes 36:963-970

5. Mandrup-Poulsen T, Bendtzen K, Nerup J et al. (1986) Mechanisms of pancreatic islet cell destruction. Dosedependent cytotoxic effect of soluble blood mononuclear cell mediators on isolated islets of Langerhans. Allergy 41: 250-259

6. Palmer J, Helqvist S, Spinas G et al. (1989) Interaction of beta-cell activity and IL-1 concentration and exposure time in isolated rat islets of Langerhans. Diabetes 38:1211-1216

7. Corbett JA, McDaniel ML (1992) Does nitric oxide mediate autoimmune destruction of $\beta$-cells? Possible therapeutic interventions in IDDM. Diabetes 41:897-903

8. Kolb H, Kolb-Bachofen V (1992) Type 1 (insulin-dependent) diabetes mellitus and nitric oxide. Diabetologia 35: 796-797

9. Eizirik DL, Pavlovic D (1997) Is there a role for nitric oxide in $\beta$-cell dysfunction and damage in IDDM? Diabetes Metab Rev 13:293-308

10. Eizirik DL, Flodstrom M, Karlsen AE et al. (1996) The harmony of the spheres: inducible nitric oxide synthase and related genes in pancreatic beta cells. Diabetologia 39: 875-890

11. Delaney CA, Pavlovic D, Hoorens A et al. (1997) Cytokines induce deoxyribonucleic acid strand breaks and apoptosis in human pancreatic islet cells. Endocrinology 138:2610-2614

12. Eizirik DL, Cagliero E, Bjorklund A et al. (1992) Interleukin- $1 \beta$ induces the expression of an isoform of nitric oxide synthase in insulin-producing cells, which in similar to that observed in activated macrophages. FEBS Lett 308: 249-252

13. Karlsen AE, Anderson HU, Vissing H et al. (1995) Cloning and expression of cytokine-inducible nitric oxide synthase cDNA from rat islets of Langerhans. Diabetes 44:753-758

14. Corbett JA, Wang JL, Sweetland MA et al. (1992) Interleukin-1beta induces the formation of nitric oxide by beta cells purified from rodent islets of Langerhans. Evidence for the beta-cells as a source and site of action of nitric oxide. J Clin Invest 90:2384-2391

15. Kroncke KD, Kolb-Bachofen V, Berschick B et al. (1991) Activated macrophages kill pancreatic syngeneic islet cells via arginine-dependent nitric oxide generation. Biochem Biophys Res Commun 175:752-758

16. Welsh N, Eizirik DL, Bendtzen K et al. (1991) Interleukin$1 \beta$-induced nitric oxide production in isolated rat pancreatic islets requires gene transcription and may lead to inhibition of the Krebs cycle enzyme aconitase. Endocrinology 129:3167-3173

17. Corbett JA, Lancaster JR, Sweetland MA et al. (1991) Interleukin-1 $\beta$-induced formation of EPR-detectable ironnitrosyl complexes in islets of Langerhans. J Biol Chem 266:21351-21354

18. Southern C, Schulster D, Green IC (1990) Inhibition of insulin secretion by interleukin- $1 \beta$ and tumor necrosis factor$\alpha$ via an L-arginine-dependent nitric oxide generating mechanism. FEBS 276:42-44

19. Rabinovitch A, Suarez-Pinzon WL (1998) Cytokines and their roles in pancreatic islet $\beta$-cell destruction and insulindependent diabetes mellitus. Biochem Pharmacol 55:1139_ 1149

20. Corbett JA, McDaniel ML (1994) Reversibility of interleukin-1 $\beta$-induced islet destruction and dysfunction by the inhibition of nitric oxide synthase. Biochem J 299:719-724

21. Naka M, Nanbu T, Kobayashi K et al. (2000) A potent inhibitor of inducible nitric oxide synthase, ONO-1714, a cyclic amidine derivative. Biochem Biophys Res Commun 270:663-667

22. Wu G (1995) Nitric oxide synthase and the effect of aminoguanidine and $\mathrm{NG}^{\mathrm{G}}$-monomethyl-L-arginine on the onset of diabetes in the spontaneously diabetic BB-rat. Diabetes 44:360-364

23. Lindsay RM, Smith W, Rossiter SP (1995) N ${ }^{\omega}{ }^{\text {-nitro-L-argi- }}$ nine methyl ester reduces the incidence of IDDM in $\mathrm{BB} / \mathrm{E}$ rats. Diabetes 44:365-368

24. Takamura T, Kato I, Kimura I et al. (1998) Transgenic mice overexpressing Type 2 nitric oxide synthase in pancreatic $\beta$ cells develop insulin-dependent diabetes without insulitis. J Biol Chem 273:2493-2496

25. Faust A, Kleemann R, Rothe H et al. (1996) Role of macrophases and cytokines in B-cell death. Lessons from animal diabetes VI. Birkhauser, Boston, pp 47-56

26. Bowman MA, Simell OG, Peck AB et al. (1996) Pharmacokinetics of aminoguanidine administration and effects on the diabetes frequency in non obese diabetic mice. J Pharmacol Exp Ther 279:790-794

27. Saurez-Pinzon WL, Mabley JG, Strynadka K (2001) An inhibitor of inducible nitric oxide synthase and scavenger of peroxynitrite prevents diabetes development in NOD mice. J Autoimmun 16:449-455

28. Ryndgren T, Sandler S (2002) Efficacy of 1400 W, a novel inhibitor of inducible nitric oxide synthase, in preventing interleukin-1-beta-induced suppression of pancreatic islet function in vitro and multiple low-dose streptozotocininduced diabetes in vivo. Eur J Endocrinol 147:543-551

29. Sampio RC, Tanus-Santos JE, Melo SEFC et al. (2002) Hypertension plus diabetes mimics the cardiomyopathy induced by nitric oxide inhibition in rats. Chest 122:14121420

30. Duplain H, Burcelin R, Sartori C et al. (2001) Insulin resistance, hyperlipidemia, and hypertension in mice lacking endothelial nitric oxide synthase. Circulation 342:342345 